\title{
The Overlapping Problems of Prosecution Sample Bias and Systematic Exclusion of Familial Child Sex Abuse Victims from the Criminal Justice System
}

\author{
Wendy J. Murphy
}

KEYWORDS. Child sex abuse, trauma, repression, criminal justice, child testimony, prosecution, memory

Jennifer Freyd's (2003) comment on Goodman et al. (2003) makes at least two essential observations: First, that Goodman's characterization of their findings as not supporting the position that CSA is "commonly" repressed or forgotten by the victim is curious. Second, that Goodman et al. understate the limited value of their study in that a prosecution sample is not generalizable to a non-prosecution population. Freyd's critique, which focuses not on the way the data was measured but the narrative explanation of the significance of the findings, raises interesting questions.

Most CSA cases accepted for prosecution are, as Freyd (2003) notes, particularly strong in terms of evidence and provability. Having risen to the level of

Wendy J. Murphy is a former child abuse and sex crimes prosecutor and a Visiting Scholar at Harvard Law School, 2002-2003. She was Mary Joe Frug Visiting Assistant Professor of Law and currently serves as Adjunct Professor at the New England School of Law in Boston. Murphy represents crime victims in criminal and civil justice proceedings.

Address correspondence to: Wendy J. Murphy, Adjunct Professor, New England School of Law, 154 Stuart Street, Boston, MA 02116.

Journal of Child Sexual Abuse, Vol. 12(2) 2003

http://www.haworthpress.com/store/product.asp?sku=J070

(C) 2003 by The Haworth Press, Inc. All rights reserved.

10.1300/J070v12n02_09 
"prosecutable" offenses, the sample studied by Goodman et al. (2003) likely excluded many viable cases that were investigated and "validated" by police or child protective services agencies-but rejected for prosecution. In my experience as a CSA prosecutor, as many as $50-75 \%$ of valid cases were rejected for prosecution. The children involved in these "rejected" valid cases were denied the supportive experience that accompanies formal criminal prosecution in terms of contextual seriousness and heightened validation from the involvement of law enforcement, and related justice professionals (Berliner \& Barbieri, 1984; Claman, Lawrence, Harris, Bernstein, \& Lovitt, 1986). Given the high percentage of valid CSA cases rejected for prosecution, it is difficult to see the value in a prosecution sample study that purports to measure the "common" memory response in children who have been sexually abused.

In addition to the factors identified by Freyd (2003), prosecution samples reflect a serious sample bias in that mandatory reporting laws disproportionately encourage the reporting of CSA that occurs outside the family. Unlike physical child abuse cases that may leave marks on a child (e.g., bruising) that are observable to a caretaker outside the family, CSA is highly dependent on the child verbally reporting abuse. When the perpetrator of CSA is an individual outside the family, the child's parents can be expected to report the crime and advocate for justice, including the use of political pressure to demand that a formal criminal proceeding be initiated. When the perpetrator is a family member, however, the child is especially vulnerable to coercive silencing efforts, and there is little hope that an adult outside the family can advocate with the effectiveness of a parent in insisting that justice be done-especially against a perpetrator who typically retains at least some authority and control over the victim. While it is certainly possible that social service agencies and law enforcement officials can remove a child from an abusive home and initiate a prosecution against a family member, the additional hurdles endured by familial CSA victims cannot be denied. Freyd correctly notes that a study sample that disproportionately excludes victims of familial abuse may well exclude the types of CSA victims with the strongest psychological incentive to repress or forget CSA because their abuse is less likely to be reported to outside officials. And even in the event of a report, victims of familial CSA are less likely to enjoy the protective advantages of formal prosecution. Left with no alternative, this category of victim may be more inclined to develop "special" psychological coping mechanisms.

Prosecution samples are also problematic because they naturally involve child victims who have many opportunities to talk about the abuse in "important" venues (e.g., with police, prosecutors, grand juries, etc.). Once accepted for prosecution, child victims are typically required to testify at preliminary hearings, and/or at grand jury proceedings, and/or during a videotape recording 
of the elements of the offense. The child and/or the child's custodial caregivers typically would be involved in ongoing conversations with the prosecutor and/or victim-witness advocate with regard to the status of the proceeding. The child may feel a "special" status by having to miss school to attend court proceedings, provide interviews, etc. And most children understand that police and other very "important" people in society are paying attention to the situation. This experience tells the child that the formal processing of a criminal case is a "special" and significant matter-which makes it more memorable than other life events. This is less likely to occur with the child whose case is valid but not accepted for prosecution.

As the prosecution case nears trial, the child may experience even more "special" attention and "reminders" of the abuse as the prosecutors take appropriate steps to "ready" the child for testimony. For example, the child might be brought to the courthouse, allowed to sit in the witness stand, reminded that adults will be asking them about what happened, that it is very "serious," that a jury will be listening, and that it is important to "tell the truth," etc. While this typically does not include practicing the details of anticipated testimony, it nevertheless involves conduct that treats the abuse experience as "different" and worthy of "extra" attention compared to other events in the child's life. This "special" attention is not accorded CSA victims whose cases are not accepted for prosecution.

Goodman et al. (2003) noted that the victims whose cases made it further into the process (i.e., those children who actually had to testify) were less likely to repress or forget than those whose cases were resolved earlier/without formal testimony. This might make sense for the reasons suggested by Freyd (2003) in that the children who testified had more opportunities to retell and thus be reminded of the abuse. However, it is also possible that those cases that went to trial were forced to do so (as opposed to being resolved by way of a plea bargain) because they involved non-familial offenders where there is typically a stronger social, political, and "family of the victim"-generated demand for the harshest possible sentence. That only $8 \%$ of the group of children who testified later failed to recall the abuse while a larger percentage of children who did not testify failed to recall the abuse may well support Freyd's (1996) betrayal theory because familial CSA victims are underrepresented in the group of children most likely to testify. Moreover because familial CSA cases are more likely to be resolved by way of a plea bargain, the victim may have a stronger psychological need to develop a "special" avoidance mechanism to cope with the trauma of CSA simply because the justice system generated a result that was inadequate to redress the victim's harm or risk of future abuse.

Given the supportive and confirmatory experience of most victims in a prosecution sample, it is stunning to see 19\% of Goodman et al.'s (2003) sam- 
ple failing to recall the abuse ten years later. Rather than characterizing this finding as not supportive of the idea that repressing or forgetting CSA is "common" (has anyone published a study concluding the experience is "common?)", Goodman et al. should have argued that such a high number in a prosecution sample is surprising and worthy of further inquiry regarding the impact of the criminal justice system on the memory of traumatized children. Did the victims experience more trauma from the system, thus develop stronger repression mechanisms? Did they simply "forget" the abuse and move on because important adults validated their harm, saw that justice was done and made them feel safe? The authors of the study, rather than Freyd (2003), should have raised these questions. That they failed to do so raises even more questions.

\section{REFERENCES}

Berliner, L., \& Barbieri, M. K. (1984). The testimony of the child victim of sexual assault. Journal of Social Issues, 40(2), 125-37.

Claman, L., Harris, J. C., Bernstein, B. E., \& Lovitt, R. (1986). The adolescent as a witness in a case of incest: Assessment and outcome. Journal of the American Academy of Child Psychiatry, 25(4), 457-61.

Freyd, J. J. (1996). Betrayal Trauma: The Logic of Forgetting Childhood Abuse. Cambridge, MA: Harvard University Press.

Freyd, J. J. (2003). Memory for abuse: What can we learn from a prosecution sample? Journal of Child Sexual Abuse, 12(2), 97-103.

Goodman, G. S., Ghetti, S., Quas, J. A., Edelstein, R. S., Alexander, K. W., Redlich, A. D., Cordon, I. M., \& Jones, D. P. H. (2003). A prospective study of memory for child sexual abuse: New findings relevant to the repressed memory controversy. Psychological Science, 14(2), 113-118. 